Article

\title{
Elucidation and Characterization of New Chlorinated By-Products after Electrochemical Degradation of Hydrochlorothiazide Using Graphite-Poly Vinyl Chloride Electrode
}

\author{
Zainab Haider Mussa ${ }^{1}$, Fouad Fadhil Al-Qaim ${ }^{1,2, *}$, Ali Yuzir ${ }^{1}$, Hirofumi Hara ${ }^{3}$, \\ Shamila Azman ${ }^{4}\left(\mathbb{D}\right.$ and Shreeshivadasan Chelliapan ${ }^{5}$ (D)
}

1 Department of Environmental Engineering and Green Technology, Malaysia-Japan International Institute of Technology, Universiti Teknologi Malaysia, Jalan Sultan Yahya Petra, Kuala Lumpur 54100, Malaysia; zp69014@yahoo.com (Z.H.M.); muhdaliyuzir@utm.my (A.Y.)

2 Department of Chemistry, Faculty of Science for Women, University of Babylon, PO Box 4, Babylon, Hilla 51001, Iraq

3 Department of Chemical Process Engineering, Malaysia-Japan International Institute of Technology, Universiti Teknologi Malaysia, Jalan Sultan Yahya Petra, Kuala Lumpur 54100, Malaysia; hhara@mjiit.jp

4 Department of Environmental Engineering, Faculty of Civil Engineering, Universiti Teknologi Malaysia, Skudai Johor 81310, Malaysia; shamila@utm.my

5 Department of Engineering, Razak Faculty of Technology and Informatics, Universiti Teknologi Malaysia, Jalan Sultan Yahya Petra, Kuala Lumpur 54100, Malaysia; shreeshivadasan.kl@utm.my

* Correspondence: fouadalkaim@yahoo.com; Tel.: +60-173-394-821

Received: 12 October 2018; Accepted: 8 November 2018; Published: 13 November 2018

check for updates

\begin{abstract}
This paper describes an electrochemical treatment process of hydrochlorothiazide (HDZ) under different conditions such as initial concentration, sodium chloride and applied voltage. In this present study, HDZ was treated by electrochemical oxidation process using graphite-PVC composite electrode as anode and Platinum $(\mathrm{Pt})$ as cathode. All results were analyzed using liquid chromatography-time of flight/mass spectrometry (LC-TOF/MS). It was found that at high applied voltages, and high amounts of $\mathrm{NaCl}$, the electrochemical treatment process was more efficient. The removal $\%$ of HDZ was $92 \%$ at $5 \mathrm{~V}$ after $60 \mathrm{~min}$. From the obtained results, the electrochemical oxidation process of HDZ followed pseudo first order with rate constant values ranged between 0.0009 and $0.0502 \mathrm{~min}^{-1}$, depending on the experimental conditions. Energy consumption was also considered in this study, it was ranged between 0.9058 and $5.56 \mathrm{Wh} / \mathrm{mg}$ using $0.5,0.3$ and $0.1 \mathrm{~g} \mathrm{NaCl}$ within interval times of $(10,20,30,40,50,60,70$, and $80 \mathrm{~min})$. Five chlorinated and one non-chlorinated by-products were formed and analyzed in negative ionization (NI) mode during the electrochemical process. Due to the strong oxidizing potential of the chlorine $\left(\mathrm{Cl}_{2}\right)$ and hypochlorite ion $\left(\mathrm{ClO}^{-}\right), \mathrm{HDZ}$ and its by-products were removed after $140 \mathrm{~min}$. Furthermore, a novel synthesis of chlorothiaizde as one of the new by-products was reported in this present study. Toxicity was impacted by the formation of the by-products, especially at $20 \mathrm{~min}$. The inhibition percentage (I\%) of E. coli bacteria was decreased to be the lowest value after $140 \mathrm{~min}$.
\end{abstract}

Keywords: hydrochlorothiazide; electrochemical oxidation process; solid phase extraction; LC-TOF/MS; toxicity 


\section{Introduction}

It is well known that pharmaceuticals are biologically active compounds, often used to reduce pain in humans and animals. In Malaysia, the analysis of pharmaceuticals is very rare except in some previous studies [1-3]. The occurrence of these compounds was observed frequently in a Malaysian aquatic environment. This frequent detection may be attributed to the fact that the conventional wastewater treatment plants are not sufficient to remove the pharmaceuticals [4,5]. Although the concentration of these pollutants is low in the environment, these pharmaceuticals may pose adverse effects on the organisms and humans due to long-term exposure [6-8].

Among these pharmaceuticals is hydrochlorothiazide, which is one of the most consumed drugs in Malaysia; between 2606 and $3443 \mathrm{~kg}$ /year was consumed from 2011-2014 as reported by the Ministry of Health [9].

Hydrochlorothiazide, chemically known as 6-chloro-3,4-dihydro-2H-1,2,4-benzothiadiazine-7sulfonamide 1,1-dioxide, is a widely used thiazide diuretic. It is used as human medicine to reduce the reabsorption of electrolytes from the renal tubules. These results increased excretion of water and electrolytes, including sodium, potassium, chloride, and magnesium [10]. Based on the literature, the removal hydrochlorothiazide was investigated by different processes. Hydrochlorothiazide was degraded under hydraulic, photocatalytic, and thermal stress conditions, however, only two by-products were separated using high performance liquid chromatography [11]. Brigante et al. [12] reported that only three by-products were generated after direct sunlight treatment of HDZ. Hydrochlorothiazide was subjected to high temperature, humidity, and UV-visible light under wide range of $\mathrm{pH}$. In one experiment, Gupta et al. [13] reported that HDZ was treated electrochemically and he found that after combination with the photocatalytic process the results were better. Consequently, he found that removal $\%$ was 50, 80, and 99\% using photocatalytic, electrochemical, and photo-electrochemical, respectively, after $80 \mathrm{~min}$ of treatment. Hydrochlorothiazide was also treated by biological treatment unit: no more than $10 \%$ was removed as reported by Radjenović et al. [14]. However, the removal of HDZ could be enhanced significantly after a combination of ozonation with a biodegradation process [15].

It is well known that electrochemical technologies have been developed to eliminate the pollutants from wastewater containing organic pollutants. These technologies could be classified into electrochemical oxidation, the electro-fenton process, electrocatalysis, and photoassisted systems [13,16-21].

In electrochemical oxidation process, the direct and indirect oxidation process could occurr on the surface of anode and/or at the bulk solution, respectively, in order to release $\mathrm{ClO}^{-} / \mathrm{HOCl}$ as an oxidizing agent [22]. Removal of pollutants depends on the active chlorine, $\mathrm{Cl}_{2} / \mathrm{ClO}^{-}$, which is strongly dependent on the presence of $\mathrm{NaCl}$ as a supporting electrolyte. This event can be explained by the primary transformation of $\mathrm{Cl}^{-}$into $\mathrm{Cl}_{2}$ then into $\mathrm{ClO}^{-} / \mathrm{HOCl}[23]$.

$$
\begin{aligned}
& 2 \mathrm{Cl}^{-} \rightarrow \mathrm{Cl}_{2}+2 \mathrm{e}^{-} \\
& \mathrm{Cl}_{2}+\mathrm{H}_{2} \mathrm{O} \rightarrow \mathrm{H}^{+}+\mathrm{Cl}^{-}+\mathrm{HOCl} \\
& \mathrm{HOCl} \leftrightarrow \mathrm{H}^{+}+\mathrm{ClO}^{-} \\
& \mathrm{ClO}^{-}+\text {organic pollutant } \rightarrow \mathrm{CO}_{2}+\mathrm{H}_{2} \mathrm{O}+\mathrm{Cl}^{-}
\end{aligned}
$$

In the degradation process, the most common question is "what is the fate of the target compound and how to identify the by-products after treatment?". The by-products could be varied depending on the type of treatment. In this report, the electrochemical oxidation process was investigated using graphite-poly vinyl chloride (PVC) as an anode. Some of the aims of the study are as follow: (1) to investigate the efficiency of the electrochemical process for the removal of HDZ under different experimental conditions, (2) to evaluate the energy consumption and kinetics during the 
electrochemical process, (3) to identify the by-products formed during the electrochemical treatment process using LC-TOF/MS as well as the evaluation of the toxicity after treatment.

\section{Results and Discussion}

\subsection{Electrochemical Catalytic Activity Evaluations}

Removal of HDZ was investigated using an electrochemical treatment process under different conditions such as initial concentration, applied voltage, and sodium chloride. It was observed that the efficiency of electrochemical process was influenced by the generation of hypochlorite ions $\left(\mathrm{ClO}^{-}\right)$, which is the most effective oxidizing agent for the removal of pollutants.

\subsubsection{Effect of Initial Concentration}

Figure 1 a shows the removal\% of $\operatorname{HDZ}$ at different initial concentration $(2,5$, and $10 \mathrm{mg} / \mathrm{L})$. Experimental results showed that the removal\% was decreased as the initial concentration increased in which it was 50, 72, and $92 \%$ using 10, 5 , and $2 \mathrm{mg} / \mathrm{L}$, respectively after $60 \mathrm{~min}$. This phenomenon has been reported previously by Mussa et al. [24]. The reason may be attributed to the fact that the number of moles of HDZ at high initial concentration is more than its number at low initial concentration.
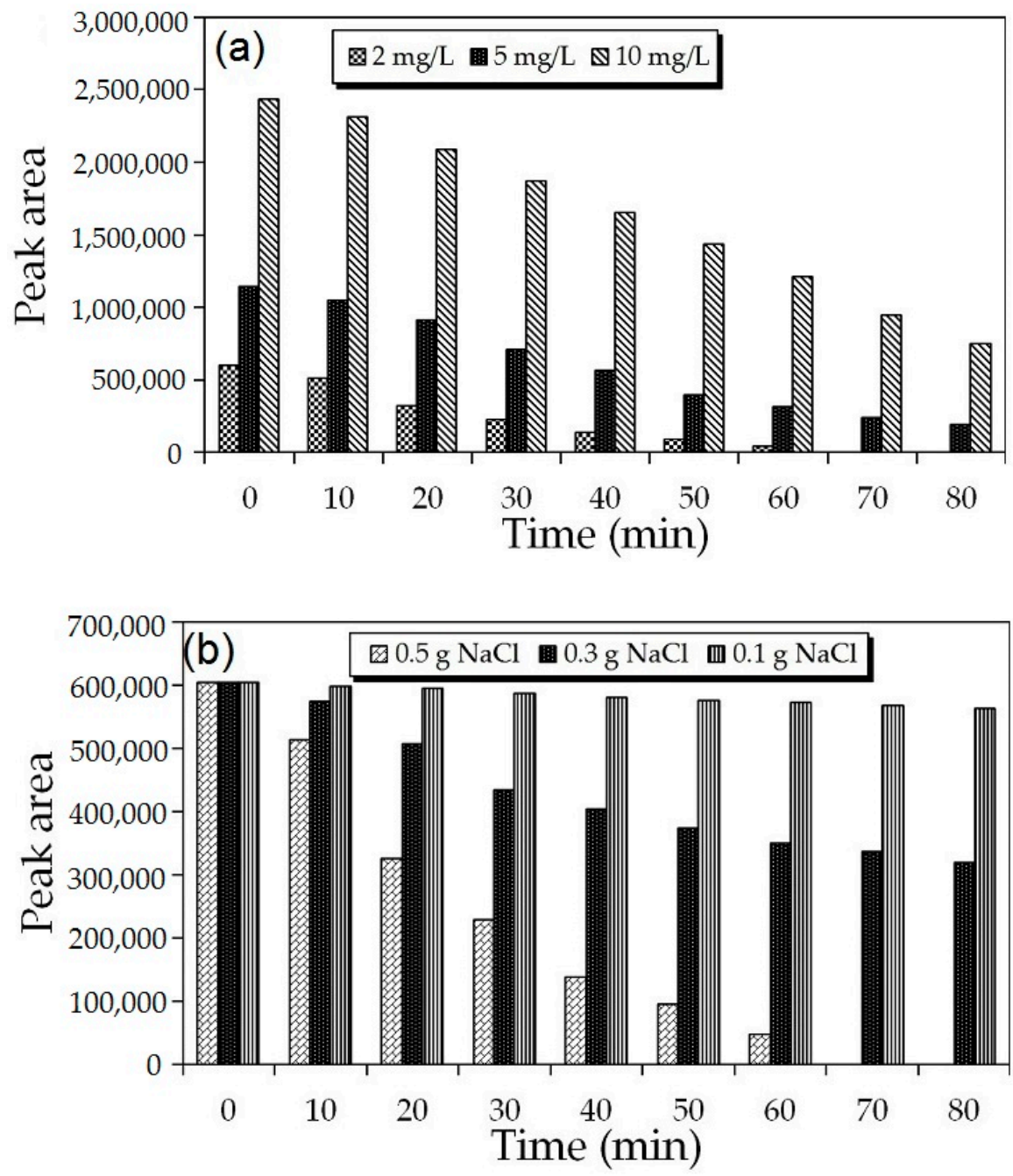

Figure 1. Cont. 


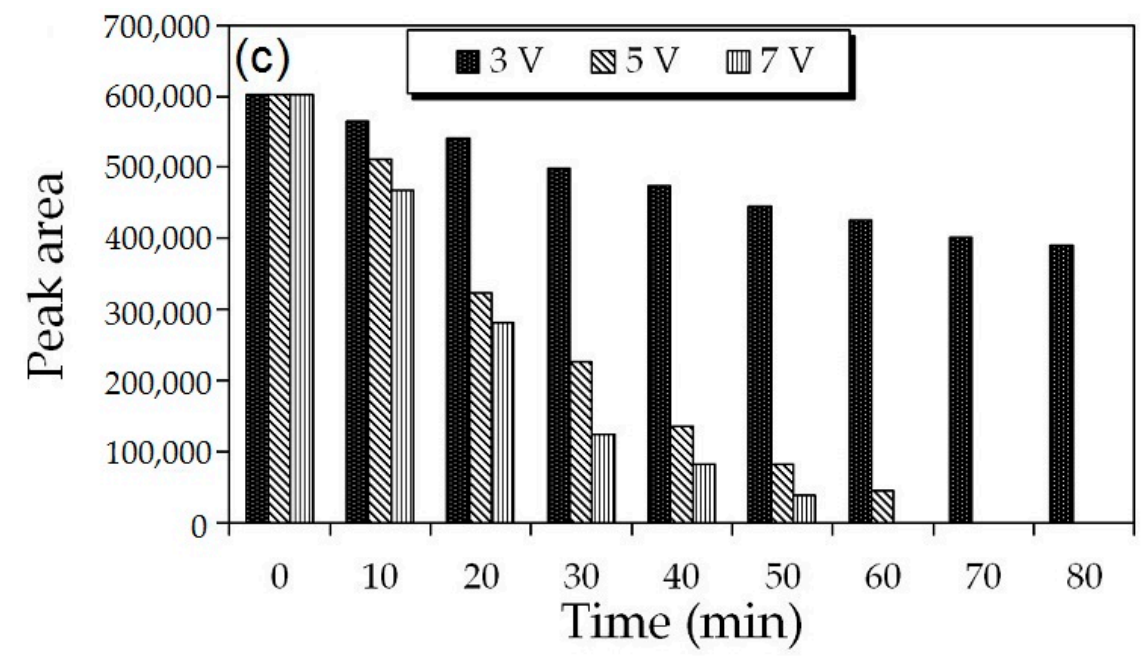

Figure 1. Effect of changing (a) initial concentration of hydrochlorothiazide on the removal $\%(0.5 \mathrm{~g} \mathrm{NaCl}$ and $5 \mathrm{~V})$; (b) amount of sodium chloride on the removal\% (2 mg/L of HDZ and $5 \mathrm{~V}$ ); (c) applied voltage on the removal\% (2 mg/L of hydrochlorothiazide (HDZ) and $0.5 \mathrm{~g} \mathrm{NaCl}$ ) throughout electrochemical oxidation process of $100 \mathrm{~mL}$ solution.

\subsubsection{Effect of $\mathrm{NaCl}$}

Several experiments were conducted to study the removal behavior under different amounts of $\mathrm{NaCl}$ $(0.1,0.3$, and $0.5 \mathrm{~g})$. Experimental results showed that the most of HDZ was eliminated effectively using graphite-PVC anode using $0.5 \mathrm{~g} \mathrm{NaCl}$. The removal of $\mathrm{HDZ}$ has been reduced sharply at low amount of $\mathrm{NaCl}$ of 0.1 and $0.3 \mathrm{~g}$ (Figure 1b). In the presence of $0.1 \mathrm{~g} \mathrm{NaCl}$, there is no significant removal of HDZ compared to other amounts of $\mathrm{NaCl}$. The role of $\mathrm{NaCl}$ using electrochemical oxidation process could be attributed to the formation of active oxidizing agent $\left(\mathrm{ClO}^{-}\right)$as presented in Equations (1)-(4).

In electrochemical oxidation process, low energy consumption is preferred unless the removal $\%$ is high (Table 1). It was observed that the highest energy consumption of $5.56 \mathrm{Wh} / \mathrm{mg}$ and low removal\% of $<1 \%$ were determined using $0.1 \mathrm{~g} \mathrm{NaCl}$ after $10 \mathrm{~min}$ of electrochemical process. Energy consumption values were mostly similar between 0.3 and $0.5 \mathrm{~g} \mathrm{NaCl}$ except at the beginning of treatment. The lowest energy consumption was $0.91 \mathrm{Wh} / \mathrm{mg}$ in the presence of $0.5 \mathrm{~g} \mathrm{NaCl}$ while it was $1.34 \mathrm{Wh} / \mathrm{mg}$ using $0.3 \mathrm{~g} \mathrm{NaCl}$ after $20 \mathrm{~min}$. From the results, $0.5 \mathrm{~g} \mathrm{NaCl}$ was the best choice for further experiments.

Table 1. Energy consumption of HDZ under effect of sodium chloride and applied voltage.

\begin{tabular}{ccccccc}
\hline & \multicolumn{3}{c}{ Energy Consumption $\mathbf{( W h} / \mathbf{m g})$} & \multicolumn{3}{c}{ Energy Consumption (Wh/mg) } \\
\cline { 2 - 7 } Time (min) & \multicolumn{3}{c}{ Effect of $\mathbf{~ N a C l} \mathbf{( g )}$} & \multicolumn{2}{c}{ Effect of Applied Voltage (V) } \\
\cline { 2 - 7 } & $\mathbf{0 . 1} \mathbf{~ g}$ & $\mathbf{0 . 3} \mathbf{~ g}$ & $\mathbf{0 . 5} \mathbf{~ g}$ & $\mathbf{3 ~ V}$ & $\mathbf{5 ~ V}$ & $\mathbf{7} \mathbf{~ V}$ \\
\hline 10 & 5.208333 & 2.488626 & 1.388888 & 0.83333 & 1.388888 & 2.386363 \\
20 & 5.555555 & 1.622934 & 0.905797 & 0.99765 & 0.905797 & 1.981132 \\
30 & 4.629629 & 1.339286 & 1.008065 & 0.88235 & 1.008065 & 1.993671 \\
40 & 4.273504 & 1.515152 & 1.08225 & 0.95238 & 1.08225 & 2.44186 \\
50 & 4.528986 & 1.644736 & 1.240079 & 0.96154 & 1.240079 & 2.822581 \\
60 & 4.90196 & 1.785714 & 1.358696 & 1.034483 & 1.358696 & - \\
70 & 4.943503 & 1.988636 & - & 1.060606 & - & - \\
80 & 4.975124 & 2.127659 & - & 1.142857 & - & - \\
\hline
\end{tabular}

\subsubsection{Effect of Applied Voltage}

Figure $1 \mathrm{c}$ showed that the effect of applied voltage on the removal\% of HDZ. Comparing the removal $\%$ of 3,5 , and $7 \mathrm{~V}$, it is obvious that the efficiency of electrochemical treatment at $7 \mathrm{~V}$ was greater than that of $3 \mathrm{~V}$. However, this finding was reported by Mussa et al. [25]. 
It is well known that high applied voltage may consume high energy so this concept was considered in this study. From Table 1, energy consumption was very high at $7 \mathrm{~V}$ comparing to $5 \mathrm{~V}$. On the other hand, removal\% was not much different between 7 and $5 \mathrm{~V}$ under same conditions. It could be concluded that the removal\% at $5 \mathrm{~V}$ is more preferred compared to $7 \mathrm{~V}$ because the energy consumption was 1.24 and $2.822 \mathrm{Wh} / \mathrm{mg}$ at 5 and $7 \mathrm{~V}$, respectively. Although energy consumption at 5 and $3 \mathrm{~V}$ is almost similar, $5 \mathrm{~V}$ was selected for further experiments due to the high removal $\%$ of $92 \%$ and $29 \%$, respectively after $50 \mathrm{~min}$.

\subsection{Electro-Reaction Kinetics}

The kinetics studies of the electrochemical oxidation process were investigated under different conditions: $\mathrm{NaCl}$ amount, applied voltage, and initial concentration as presented in Table 2. It is well known that most of catalytic reactions could follow a second-order reaction, as described by the Equation (5) $[26,27]$.

$$
\frac{\mathrm{d}[\mathrm{HDZ}]_{\mathrm{t}}}{\mathrm{dt}}=-k_{\mathrm{app}}[\mathrm{ClO}]_{\mathrm{t}}^{-}[\mathrm{HDZ}]_{\mathrm{t}}
$$

where $k_{\mathrm{app}}$ is the apparent second-order rate coefficient; $\left[\mathrm{ClO}^{-}\right]_{\mathrm{t}}$ is the total concentration of $\mathrm{ClO}^{-}$ species at the reaction time of $\mathrm{t}$; $\mathrm{HDZ}]_{\mathrm{t}}$ is the total concentration of the $\mathrm{HDZ}$ at the reaction time of $\mathrm{t}$.

Table 2. Pseudo first order rate constants for hydrochlorothiazide under different conditions such as initial concentration, sodium chloride concentration and applied voltage.

\begin{tabular}{|c|c|c|c|c|c|}
\hline Parameters & Quantity & No. Points & Kinetic Equation & Rate Constant $\left(\min ^{-1}\right)$ & Correlation Coefficient $\left(\mathrm{R}^{2}\right)$ \\
\hline \multirow{3}{*}{ Initial concentration (mg/L) } & 2 & 6 & $\operatorname{Ln}(\mathrm{A} / \mathrm{At})^{*}=-0.0379 \times$ & 0.0379 & 0.9673 \\
\hline & 5 & 8 & $\operatorname{Ln}(\mathrm{A} / \mathrm{At})=-0.0210 \times$ & 0.0210 & 0.9684 \\
\hline & 10 & 8 & $\operatorname{Ln}(\mathrm{A} / \mathrm{At})=-0.0125 \times$ & 0.0125 & 0.9334 \\
\hline \multirow{3}{*}{ Sodium chloride (g) } & 0.1 & 8 & $\operatorname{Ln}(\mathrm{A} / \mathrm{At})=-0.0009 \times$ & 0.0009 & 0.9917 \\
\hline & 0.3 & 8 & $\operatorname{Ln}(\mathrm{A} / \mathrm{At})=-0.0087 \times$ & 0.0087 & 0.9642 \\
\hline & 0.5 & 6 & $\operatorname{Ln}(\mathrm{A} / \mathrm{At})=-0.0379 \times$ & 0.0379 & 0.9673 \\
\hline Applied voltage (V) & 7 & 5 & $\operatorname{Ln}(\mathrm{A} / \mathrm{At})=-0.0502 \times$ & 0.0502 & 0.9710 \\
\hline
\end{tabular}

In the presence of a high excess of $\mathrm{ClO}^{-}$, the concentration remains always constant throughout the reaction (i.e., $\left[\mathrm{ClO}^{-}\right]_{\mathrm{t}}=\left[\mathrm{ClO}^{-}\right]_{0}$ ). Hence, $k_{\mathrm{app}}$. $\left[\mathrm{ClO}^{-}\right]_{\mathrm{t}}$ could be regarded as a constant so the pseudo-first-order kinetic constant $k_{\mathrm{obs}}$ is introduced as obtained in Equation (6).

$$
\frac{\mathrm{d}[\mathrm{HDZ}]_{\mathrm{t}}}{\mathrm{dt}}=-k_{\mathrm{obs}}[\mathrm{HDZ}]_{\mathrm{t}}
$$

After integration Equation (6) and rearranged it, Equation (7) could be presented as follow:

$$
\ln \left([\mathrm{HDZ}]_{\mathrm{t}} /[\mathrm{HDZ}]_{0}\right)=-k_{\text {obs }} \mathrm{t}
$$

According to this equation, $\ln \left([\mathrm{HDZ}]_{\mathrm{t}} /[\mathrm{HDZ}]_{0}\right)$ was plotted versus time to generate straight line, correlation coefficient $\left(\mathrm{R}^{2}\right) \geq 0.9334$, with a slope of $-k_{\mathrm{obs}}$. Electrocatalytic-kinetics rate constants were presented in Table 2. It was observed that in the presence of $\mathrm{NaCl}$ and high applied voltage, the rate constant value becomes high. The reason may be attributed to the generation of $\mathrm{ClO}^{-}$, which contributes strongly for the elimination of HDZ. However, the values of $k_{\text {obs }}$ were $0.0379,0.0087$, and $0.0009 \mathrm{~min}^{-1}$ in the presence of $0.5,0.3$, and $0.1 \mathrm{~g} \mathrm{NaCl}$, respectively. In case of applied voltage, high $k_{\mathrm{obs}}$ of $0.0502 \mathrm{~min}^{-1}$ was observed at $7 \mathrm{~V}$ which is (1.3) times greater than $k_{\mathrm{obs}}$ at $5 \mathrm{~V}$ and ten times greater than $k_{\mathrm{obs}}$ at $3 \mathrm{~V}$. For further investigation, electro-reaction kinetics was tested at different initial concentration of HDZ. From Table 2, the highest rate constant was conserved with the lowest initial concentration. $k_{\text {obs }}$ values were arranged as follow: $0.0379,0.0210$, and $0.0125 \mathrm{~min}^{-1}$ for 2, 5, and $10 \mathrm{mg} / \mathrm{L}$, respectively. The reason why low $k_{\mathrm{obs}}$ was obtained with high initial concentration at 
fixed volume $(100 \mathrm{~mL})$ may due to the fact that the number of molecules of $\mathrm{HDZ}$ at $10 \mathrm{mg} / \mathrm{L}$ which is more than its number of molecules at $2 \mathrm{mg} / \mathrm{L}$.

\subsection{Identification of the By-Products}

In this present study, LC-TOF/MS chromatograms of the degradation solution of HDZ were constructed. In general, five chlorinated and one non-chlorinated by-products were identified and analyzed under following conditions: concentration of HDZ of $200 \mu \mathrm{g} / \mathrm{L}$, applied voltage of $5 \mathrm{~V}$, sample volume of $100 \mathrm{~mL}$ and $0.5 \mathrm{~g} \mathrm{NaCl}$ after $20 \mathrm{~min}$ of electrochemical oxidation process.

\subsubsection{Monitoring the By-Products}

Figure 2 shows the profile chromatogram for the separation of by-products on Gemini $5 \mu \mathrm{m}$ NX $110 \AA$ C18 column $(2 \mathrm{~mm} \times 150 \mathrm{~mm}$, phenomenex $)$ using LC-TOF/MS. It was observed that the extracted ion chromatograms (EIC) after $20 \mathrm{~min}$ of electrochemical treatment were well separated and identified. All products were detected in NI mode with high signal-to-noise ratio $(\mathrm{S} / \mathrm{N})$ ranged between 60 and 628 .

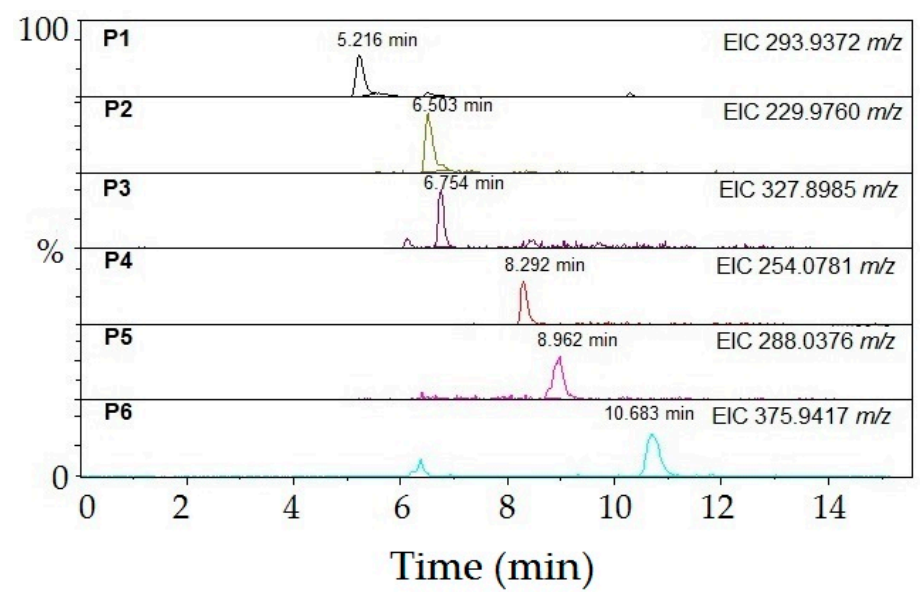

Figure 2. Liquid chromatography-time of flight/mass spectrometry (LC-TOF/MS) chromatograms of all HDZ by-products.

All by-products were monitored within $160 \mathrm{~min}$ to evaluate the efficiency of electrochemical oxidation process. LC-TOF/MS instrument revealed the formation of P1, P2, P3, P4, P5 and P6 at retention times $\left(t_{R}\right)$ of $5.216,6.503,6.754,8.292,8.962$ and $10.683 \mathrm{~min}$, respectively after $20 \mathrm{~min}$ of electrochemical oxidation process. The appearance and dis-appearance profile as presented in Figure 3 is an indication of the formation the by-products.

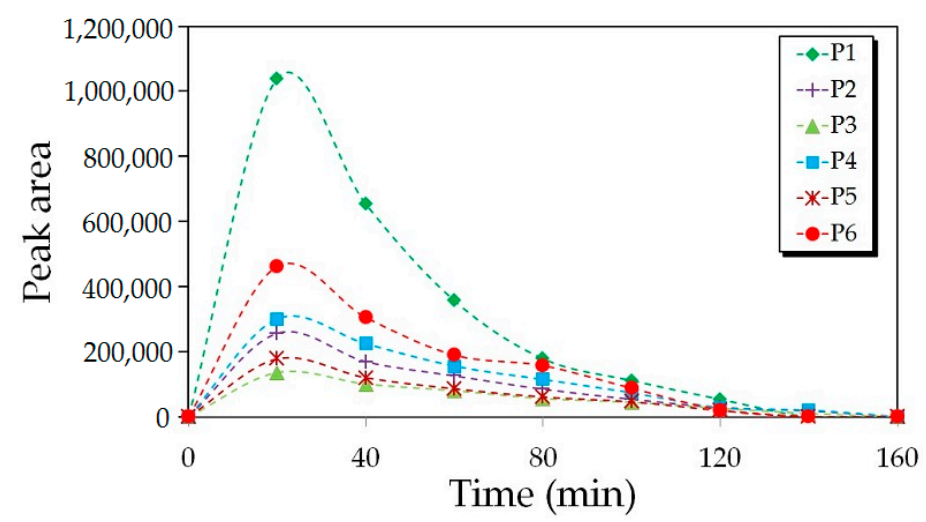

Figure 3. Monitoring the by-products using LC-TOF/MS: $100 \mathrm{~mL}$ of solution, $5 \mathrm{~V}, 0.5 \mathrm{~g} \mathrm{NaCl}$, and $200 \mu \mathrm{g} / \mathrm{L} \mathrm{HDZ}$. 
As observed in the formation profile curves, the by-products were generated completely after 20 min of treatment then they were decreased with the time.

\subsubsection{Electrochemical Oxidation Pathway of HDZ}

Few studies were reported about the identification of the by-products of HDZ so to achieve this critical point, the electrochemical degraded sample was analyzed in NI mode using LC-TOF/MS. Table 3 presents the retention times, elemental composition and accuracies (in ppm) for all by-products.

Table 3. Accurate mass measurements obtained by LC-TOF/MS for the by-products after electrochemical oxidation treatment of hydrochlorothiazide.

\begin{tabular}{cccccc}
\hline By-Products & $\mathbf{t}_{\mathbf{R}}(\mathbf{m i n})$ & Composition Molecular Ion & Error $(\mathbf{p p m})$ & $\boldsymbol{m} / \boldsymbol{z}$ & $\mathrm{S} / \mathbf{N}$ \\
\hline P1 & 5.216 & $\mathrm{C}_{7} \mathrm{H}_{5} \mathrm{ClN}_{3} \mathrm{O}_{4} \mathrm{~S}_{2}$ & 0.3 & 293.9372 & 628 \\
P2 & 6.503 & $\mathrm{C}_{7} \mathrm{H}_{5} \mathrm{ClN}_{3} \mathrm{O}_{2} \mathrm{~S}$ & 0.16 & 229.9760 & 158 \\
P3 & 6.754 & $\mathrm{C}_{7} \mathrm{H}_{4} \mathrm{Cl}_{2} \mathrm{~N}_{3} \mathrm{O}_{4} \mathrm{~S}_{2}$ & -0.29 & 327.8985 & 60 \\
P4 & 8.292 & $\mathrm{C}_{7} \mathrm{H}_{16} \mathrm{~N}_{3} \mathrm{O}_{5} \mathrm{~S}$ & 0.33 & 254.0781 & 113 \\
P5 & 8.962 & $\mathrm{C}_{7} \mathrm{H}_{15} \mathrm{ClN}_{3} \mathrm{O}_{5} \mathrm{~S}$ & 0.48 & 288.0376 & 63 \\
P6 & 10.683 & $\mathrm{C}_{7} \mathrm{H}_{14} \mathrm{Cl}_{4} \mathrm{~N}_{3} \mathrm{O}_{4} \mathrm{~S}$ & 0.19 & 375.9417 & 108 \\
\hline
\end{tabular}

The molecular formula for all by-products: P1, P2, P3, P4, P5, and P6 were $\mathrm{C}_{7} \mathrm{H}_{5} \mathrm{ClN}_{3} \mathrm{O}_{4} \mathrm{~S}_{2}$, $\mathrm{C}_{7} \mathrm{H}_{5} \mathrm{ClN}_{3} \mathrm{O}_{2} \mathrm{~S}, \mathrm{C}_{7} \mathrm{H}_{4} \mathrm{Cl}_{2} \mathrm{~N}_{3} \mathrm{O}_{4} \mathrm{~S}_{2}, \mathrm{C}_{7} \mathrm{H}_{16} \mathrm{~N}_{3} \mathrm{O}_{5} \mathrm{~S}, \mathrm{C}_{7} \mathrm{H}_{15} \mathrm{ClN}_{3} \mathrm{O}_{5} \mathrm{~S}$, and $\mathrm{C}_{7} \mathrm{H}_{14} \mathrm{Cl}_{4} \mathrm{~N}_{3} \mathrm{O}_{4} \mathrm{~S}$, respectively. Only one by-product (P4) was non-chlorinated while the other five are chlorinated by-products as presented in Scheme 1.

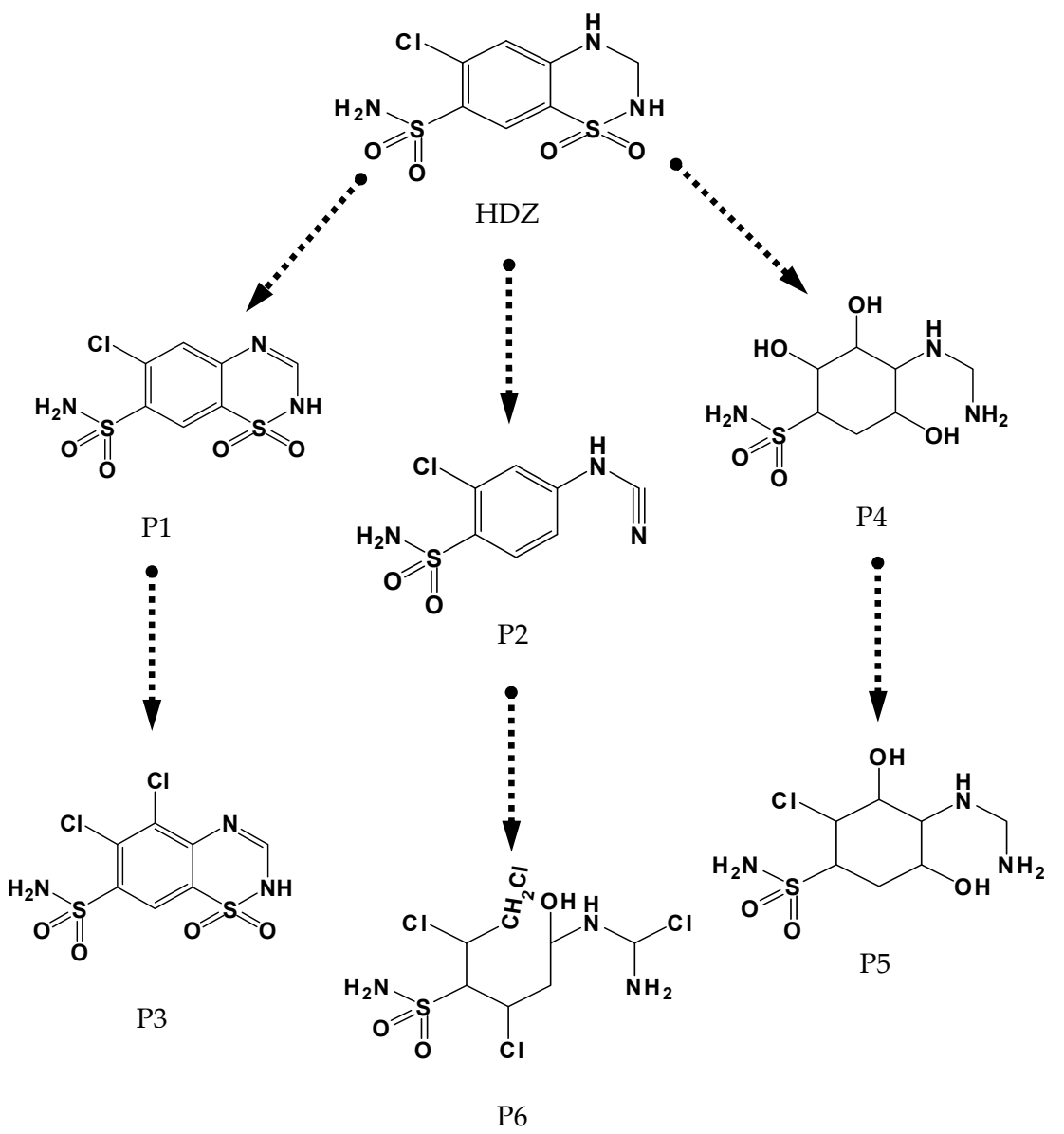

Scheme 1. Proposed pathway degradation of the by-product. 
In this present study, it was observed that chlorothiazide (P1), a diuretic and antihypertensive drug, was synthesized after electrochemical oxidation of HDZ. However, the common reaction in this process is the substitution of chlorine atom(s) on the HDZ structure resulting more chlorinated by-products. It was observed that $\mathrm{P} 1$ and $\mathrm{P} 2$ are derived from substitution of one and two chlorine atoms on HDZ structure without any cleavage for the rings. The other products were derived from the cleavage of the ring(s), saturation of the rings and oxidation reaction.

Figure 4 shows the formation of five chlorinated by-products in the presence of chlorine in the solution. The oxidation reaction pathway was occurred via hypochlorite ion $\mathrm{ClO}^{-}$as reported by Soufan et al. [28]. During the electrochemical oxidation, several compounds will be produced in the solution, which is very difficult to identify them because the electrochemical process is non-selective so it is very important to use an accurate instrument "LC-TOF/MS" for this purpose.
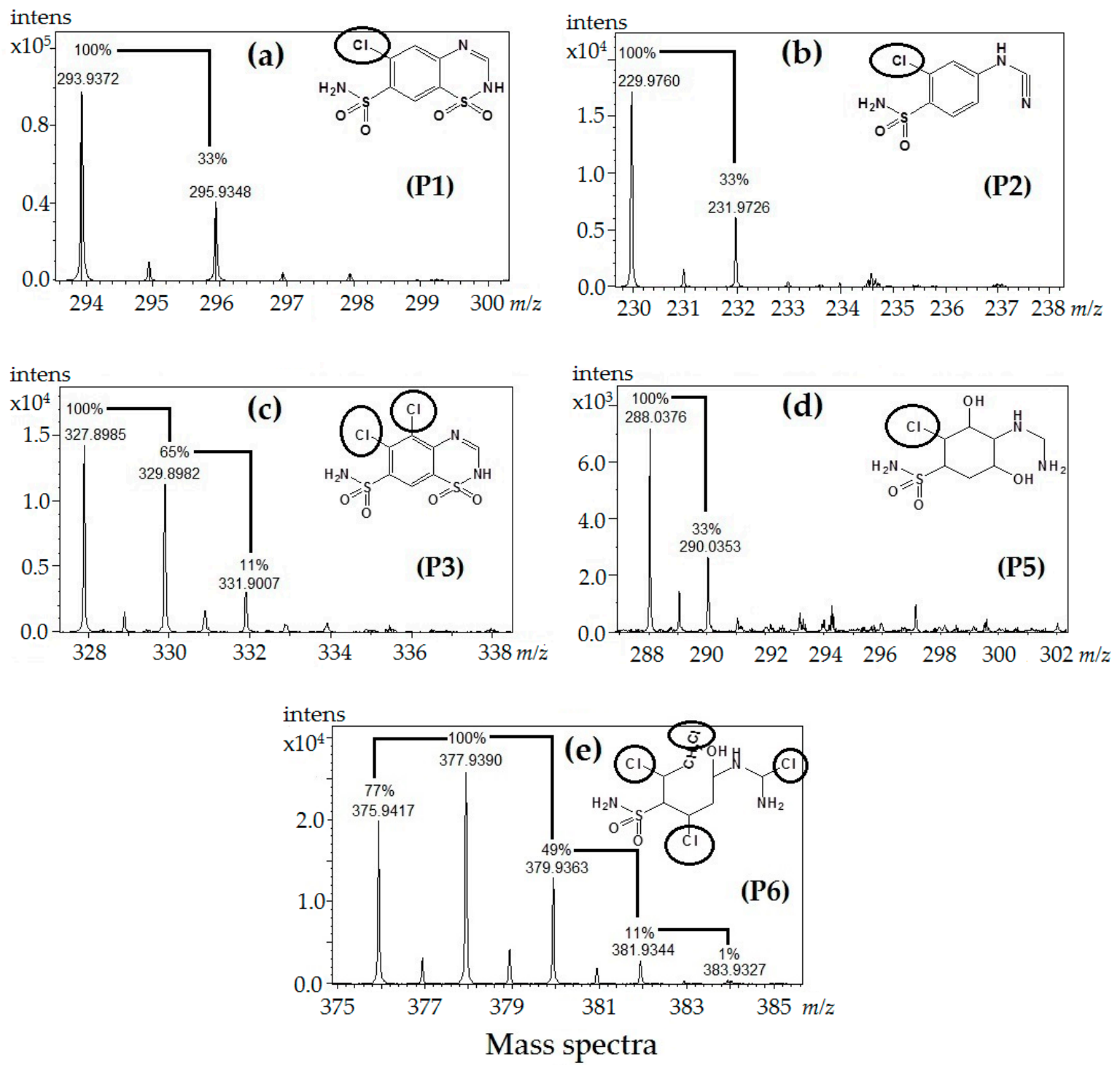

Figure 4. Elucidation profile of the chlorinated by-products during electrochemical oxidation process of HDZ; (a,b,d) mono-chlorine atoms; (c) di-chlorine at oms; (e) tetra-chlorine atoms.

This report is the first to report the formation of chlorothiazide and to elucidate the new chlorinated by-products after electrochemical treatment of hydrochlorothiazide. Three by-products exhibit mono chlorine-HDZ by-products as presented in Figure $4 \mathrm{a}, \mathrm{b}, \mathrm{d}$. It was observed that all these compounds have different structural formula but similar intensities in the mass spectra for the two main peaks $(100 \% \rightarrow 33 \%)$ as follow: 
$m / z$ 293.9372 $\rightarrow 295.9348, m / z 229.9760 \rightarrow 231.9726$ and $m / z$ 288.0376 $\rightarrow 290.0353$, respectively. Figure $4 \mathrm{c}$, presents the di chlorine-HDZ by-product $\left(\mathrm{C}_{7} \mathrm{H}_{4} \mathrm{Cl}_{2} \mathrm{~N}_{3} \mathrm{O}_{4} \mathrm{~S}_{2},-0.29 \mathrm{ppm}\right)$, which has two chlorine atoms in the structure. However, the mass spectra profile exhibited three main peaks at $m / z 327.8985,329.8982$ and 331.9007 with main probabilities of $100 \%: 65 \%: 11 \%$, respectively. After careful examination of the ion cluster in Figure 4e, it was observed that it should be multi-chlorine-HDZ product there. The five main mass peaks of $m / z$ 375.9417, 377.9390, 379.9363, 381.9344, and 383.9327 were separated by $m / z 2$ unit. The isotopic peak abundance ratio of 77\%:100:49\%:11\%:1\%, indicating that this product contained four chlorine atoms.

\subsection{Toxicity Assessment}

Toxicity is an important factor in the assessment of the electrochemical process in terms of the ecological risk of HDZ and its by-products.

It is very common that some by-products are more toxic than parent compound itself so evolution of the toxicity for HDZ and its by-products is necessary.

Toxicity was investigated by measuring changes in the neutral emission of the luminescent bacteria $E$. coli in samples collected after different interval times $(0,20,40,60,80,100,120,140$, and $160 \mathrm{~min}$ ).

Based on the results in Table 4, the sharp inhibition of bacteria (73-68\%) was observed between 20 and $40 \mathrm{~min}$ of electrolysis process, this trend may be attributed to the formation of by-products at highest concentration. Toxicity is completely impacted by by-products, however, after $100 \mathrm{~min}$ the inhibition of bacteria was less compared to its inhibition before treatment (i.e., in the presence of HDZ only). This finding may be attributed to the fact that HDZ and its by-products were eliminated.

Table 4. Toxicity evolution of HDZ after electrochemical oxidation process.

\begin{tabular}{cccccccccc}
\hline Time (min) & 0 & 20 & 40 & 60 & 80 & 100 & 120 & 140 & 160 \\
\hline $\mathbf{I} \%$ & $43 \%$ & $73 \%$ & $68 \%$ & $57 \%$ & $46 \%$ & $40 \%$ & $35 \%$ & $33 \%$ & $31 \%$ \\
\hline
\end{tabular}

\section{Experimental}

Hydrochlorothiazide was supplied by Sigma-Aldrich (St. Louis, MO, USA, $\geq 98 \%$ ). Organic solvents and other chemicals used were HPLC-grade from Sigma-Aldrich (St. Louis, MO, USA, $\geq 98 \%$ ). Graphite powder was obtained from University Kebangsaan Malaysia (Bangi, Malaysia). All aqueous solutions were prepared with de-ionized water (DIW) with conductivity $\leq 18 \mathrm{~S} / \mathrm{cm}$ at ambient temperature. $\mathrm{NaCl}$ was purchased from Merck (Darmstadt, Germany) with high purity $\geq 99.5 \%$. Escherichia coli (ATCC 25922/USA) bacteria was collected from Ecological Engineering lab, Malaysia-Japan International Institute of Technology (Kuala Lumpur, Malaysia). Mueller Hinton Broth as nutrient broth was obtained from Merck (Darmstadt, Germany).

\subsection{The Electrochemical Cell}

The electrochemical cell consists of the cathode, a platinum sheet of $1.5 \times 1.5 \mathrm{~cm}$ dimensions, and the anode, graphite-PVC composite, which was opposite to the cathode and separated by $4 \mathrm{~cm}$. The anode was bonded to cupper or silver wire using epoxy paint glue and it was $20 \mathrm{~mm}$ diameter. A full scheme of making graphite-PVC electrode pellet was shown in Figure 5. The electrodes were operated using DC power supply, Thurlby Thandar Instruments Ltd, St., Ives Cambridgeshire, England (CPX200 DUAL, 35 V 10 A PSU). The electrochemical cell volume was about $100 \mathrm{~mL}$. All detailed information for the preparation of the electrodes (cathode and anode) was reported by our previous study [25]. 


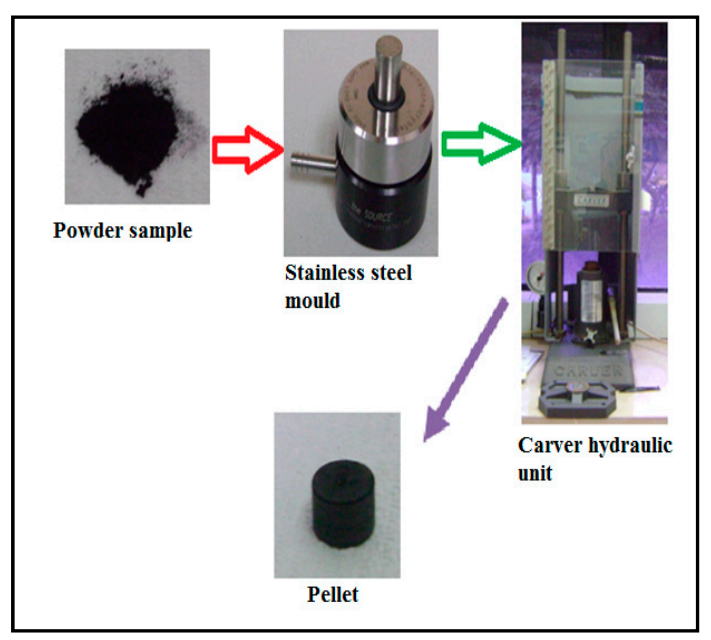

Figure 5. Steps of preparing graphite-PVC pellet.

A $100 \mathrm{~mL}$ of HDZ solution was electrochemically treated at different intervals $(0,10,20,30,40,50$, 60,70 , and 80). However, energy consumption was investigated at different values of applied voltages and sodium chloride during the electrochemical oxidation process to ensure that the present study is preferred for this purpose. HDZ was tested without switching on power as a control test to confirm that the removal of HDZ is not due to the adsorption to the electrodes.

A solution of $2 \mathrm{mg} / \mathrm{L}$ was subjected to non-electrochemical process (i.e., switch off DC power) for $60 \mathrm{~min}$ at a fixed amount of $0.5 \mathrm{~g} \mathrm{NaCl}$. All samples were analyzed and compared to the origin solution using LC-TOF/MS.

\subsection{Preparation of HDZ Solution}

Hydrochlorothiazide $(0.01 \mathrm{~g})$ dissolves in $10 \mathrm{~mL}$ of methanol to prepare a stock solution of $1000 \mathrm{mg} / \mathrm{L}$. Subsequent concentrations 2,5 and $10 \mathrm{mg} / \mathrm{L}$ were prepared after diluting in de-ionized water.

\subsection{Extraction of the By-Products}

To identify the by-products, electrochemical treatment experiments were performed in $100 \mathrm{~mL}$ of $\mathrm{HDZ}$ solution. The initial concentration of HDZ was $200 \mu \mathrm{g} / \mathrm{L}$ in the presence of sodium chloride of $0.5 \mathrm{~g}$ and applied voltage of $5 \mathrm{~V}$. After 20, 40, 60, 80, 100, 120, 140, and $160 \mathrm{~min}$, a $100 \mathrm{~mL}$ of treated samples were subjected to the following pre-treatment samples using solid phase extraction (SPE) before their injection to LC-TOF/MS. All samples were filtered using 0.45 Whatman (Little, Chalfont, UK) filter paper and then loaded to Oasis HLB ( 3 cc, $60 \mathrm{mg}$, Waters, Milford, MA, USA) cartridges using a 10-sample vacuum manifold which was first preconditioned with $2 \mathrm{~mL} \mathrm{MeOH}$ and $2 \mathrm{~mL}$ DIW. The samples were loaded at a flow rate of $3 \mathrm{~mL} / \mathrm{min}$ under vacuum conditions. Cartridges were dried under vacuum for $5 \mathrm{~min}$ at $15 \mathrm{~mL} / \mathrm{min}$ to remove residual water. All by-products were subsequently eluted to $12 \mathrm{~mL}$ glass tubes by sequentially passing $5 \mathrm{~mL}$ methanol. After that, evaporation until dryness was achieved under a gentle stream of $\mathrm{N}_{2}$ gas. Dry extracts were reconstituted with $1.0 \mathrm{~mL} \mathrm{MeOH}-\mathrm{DIW}(10: 90, v / v), 30 \mu \mathrm{L}$ of the extract was automatically injected into the LC-TOF/MS system for analysis.

\subsection{Chemical Analysis}

LC-TOF/MS separation of the degradation solutions were preliminarily performed on a Gemini 5 $\mu \mathrm{m}$ NX 110 ̊ C18 column ( $2 \mathrm{~mm} \times 150 \mathrm{~mm}$, Phenomenex) by a Dionex Ultimate 3000/LC 09115047 (Sunnyvale, CA, USA) system equipped with a vacuum degasser, a quaternary pump, and an auto-sampler. Data were acquired by the Brucker DataAnalysis software (Fahrenheitstr.4, Bremen, Germany). The origin compound and its by-products were analyzed only in NI mode, however, no any compound was detected in positive ionization (PI) mode. The mobile phase and elution 
program were presented in Table 5 . The by-products were detected as de-protonated molecular ions $[\mathrm{M}-\mathrm{H}]^{-}$. Additional confirmation of the by-products identity was accompanied by retention time. Further detailed information for the mass setting could be referred to the previous study [25].

Table 5. Chromatographic separation of hydrochlorothiazide and its by-products for NI modes.

\begin{tabular}{|c|c|c|c|c|c|c|}
\hline \multicolumn{7}{|c|}{ Negative Ion } \\
\hline Mobile Phase & & $\begin{array}{r}\text { A: } \\
\text { B: AC }\end{array}$ & $\begin{array}{l}\% \mathrm{FA} \\
\mathrm{MeOH}\end{array}$ & $\begin{array}{l}\text { DIW } \\
: 3, v /\end{array}$ & & \\
\hline Flow Rate & & & $\mathrm{mL} /$ & & & \\
\hline Injection Volume & & & $30 \mu$ & & & \\
\hline Gradient Program & $\begin{array}{c}\text { Time (min) } \\
\text { B } \%\end{array}$ & $\begin{array}{c}0 \\
5 \%\end{array}$ & $\begin{array}{c}5 \\
95 \%\end{array}$ & $\begin{array}{c}10 \\
95 \%\end{array}$ & $\begin{array}{c}10.1 \\
5 \%\end{array}$ & $\begin{array}{c}15.1 \\
5 \%\end{array}$ \\
\hline
\end{tabular}

\subsection{Toxicity Test}

After electrochemical oxidation process, the toxicity of HDZ and its by-products was evaluated on samples collected at different intervals $(0,20,40,60,80,100,120,140$ and $160 \mathrm{~min})$. Toxicity measurements were performed by modified ToxTrak ${ }^{\mathrm{Tm}}$ method 10017 using HACH UV-spectrophotometer instrument (model DR 2600, Woodbridge, VA, USA), based on the determination of the inhibition of the bioluminescence of the bacterium Escherichia coli (ATCC 25922). It was activated by adding $1.0 \mathrm{~mL}$ of E. coli to $20 \mathrm{~mL}$ of Mueller Hinton nutrient broth Merck, (Darmstadt, Germany) then incubated for $24 \mathrm{~h}$ at $37^{\circ} \mathrm{C}$ until becoming turbid (turbidity indicates bacterial growth). However, $1.0 \mathrm{~mL}$ of activated bacteria and $1.0 \mathrm{~mL}$ of broth were added to $1.0 \mathrm{~mL}$ of treated samples after different intervals, then all samples were incubated for $24 \mathrm{~h}$ at $37^{\circ} \mathrm{C}$.

These assays are based on the decay of the light emitted by the bacterium when exposed to toxic chemical compounds. The percentage of inhibition (I\%) was calculated according to Equation (8).

$$
\mathrm{I} \%=\left[1-\frac{\mathrm{Abs}_{\mathrm{s}}}{\mathrm{Abs}_{\mathrm{C}}}\right] \times 100 \%
$$

where $\mathrm{I} \%$ is the percentage of inhibition; $\mathrm{Abs}_{\mathrm{s}}$ is the absorbance of treated sample; $\mathrm{Abs}_{\mathrm{C}}$ is the absorbance of control sample.

\section{Conclusions}

In this research work, hydrochlorothiazide was treated using electrochemical oxidation process. The electrochemical process showed that HDZ and its by-products were eliminated within 140-160 min using graphite-PVC composite electrode. This present study was reported for the first time explaining the elucidation of the formation of chlorinated by-products. Electrochemical oxidation process for HDZ was investigated in the presence of $\mathrm{NaCl}$ as supporting electrolyte under different applied voltage. Pseudo first-order kinetics was the dominant during the treatment process in which the rate constant was ranged between 0.0009 and $0.0379 \mathrm{~min}^{-1}$.

The formation of chlorinated products was enhanced strongly at the first $20 \mathrm{~min}$ then most of by-products were eliminated after $80 \mathrm{~min}$. Six by-products were formed and analyzed using LC-TOF/MS. However, chlorothiaizde, a diuretic and antihypertensive drug, was investigated as one of the by-products in the present study. The formation of chlorinated by-products exhibited an impact of bacteria in which the inhibition was $73 \%$ at $20 \mathrm{~min}$. However, the toxicity was reduced to be $35 \%$ after $130 \mathrm{~min}$.

Author Contributions: Z.H.M. and F.F.A.-Q. initiated the research work. The electrochemical process setup and preparation of graphite-PVC composite were conducted by Z.H.M. Elucidation of the by-products using LC-TOF/MS was provided by F.F.A.-Q. Funding Acquisition was provided by A.Y., H.H., S.A. and S.C. Revision the manuscript before submission was provided by H.H. All authors read and approved the final manuscript. 
Funding: The authors would like to thank Universiti Teknologi Malaysia (UTM) and the Ministry of Higher Education Malaysia (MOHE) for funding this research under Grant No. 4J284 and 4F807. Furthermore, this work was also financial supported under grant Professional Development Research University (PDRU) Grant No: 04E52.

Acknowledgments: Support for this study was provided by Malaysia-Japan International Institute of Technology (MJIIT). Management Research, Universiti Teknologi Malaysia. The authors thank Alefee who is the person in-charge of LC-TOF/MS. The authors would like to thank Universiti Teknologi Malaysia (UTM) and the Ministry of Higher Education Malaysia (MOHE) for funding this research under Grant No. 4J284 and 4F807. Furthermore, this work was also financial supported under grant Professional Development Research University (PDRU) Grant No: 04E52.

Conflicts of Interest: The authors declare no conflict of interest.

\section{References}

1. Al-Odaini, N.A.; Zakaria, M.P.; Yaziz, M.I.; Surif, S. Multi-residue analytical method for human pharmaceuticals and synthetic hormones in river water and sewage effluents by solid-phase extraction and liquid chromatography-tandem mass spectrometry. J. Chromatogr. A 2010, 1217, 6791-6806. [CrossRef] [PubMed]

2. Al-Qaim, F.F.; Abdullah, M.P.; Othman, M.R.; Mussa, Z.H.; Zakaria, Z.; Latip, J.; Afiq, W.M. Investigation of the environmental transport of human pharmaceuticals to surface water: A case study of persistence of pharmaceuticals in effluent of sewage treatment plants and hospitals in Malaysia. J. Braz. Chem. Soc. 2015, 26, 1124-1135. [CrossRef]

3. Al-Qaim, F.F.; Abdullah, M.P.; Othman, M.R.; Latip, J.; Afiq, W. A validation method development for simultaneous LC-ESI-TOF/MS analysis of some pharmaceuticals in Tangkas river-Malaysia. J. Braz. Chem. Soc. 2014, 25, 271-281. [CrossRef]

4. Al-Qaim, F.F.; Mussa, Z.H.; Yuzir, A. Development and validation of a comprehensive solid-phase extraction method followed by LC-TOF/MS for the analysis of eighteen pharmaceuticals in influent and effluent of sewage treatment plants. Anal. Bioanal. Chem. 2018, 410, 4829-4846. [CrossRef] [PubMed]

5. Al-Qaim, F.F.; Mussa, Z.H.; Yuzir, A.; Tahrim, N.; Hashim, N.; Azman, S. Transportation of Different Therapeutic Classes of Pharmaceuticals to the Surface Water, Sewage Treatment Plant, and Hospital Samples, Malaysia. Water 2018, 10, 916. [CrossRef]

6. Feng, L.; Van Hullebusch, E.D.; Rodrigo, M.A.; Esposito, G.; Oturan, M.A. Removal of residual anti-inflammatory and analgesic pharmaceuticals from aqueous systems by electrochemical advanced oxidation processes. A review. Chem. Eng. J. 2013, 228, 944-964. [CrossRef]

7. Nikolaou, A.; Meric, S.; Fatta, D. Occurrence patterns of pharmaceuticals in water and wastewater environments. Anal. Bioanal. Chem. 2007, 387, 1225-1234. [CrossRef] [PubMed]

8. Zhang, Y.; Geißen, S.U.; Gal, C. Carbamazepine and diclofenac: Removal in wastewater treatment plants and occurrence in water bodies. Chemosphere 2008, 73, 1151-1161. [CrossRef] [PubMed]

9. Malaysian Statistics on Medicine, Ministry of Health Malaysia, Kuala Lumpur. Available online: http:/ /apps. who.int/medicinedocs/documents/s17580en/s17580en.pdf (accessed on 7 July 2018).

10. Drugbank. Available online: https://www.drugbank.ca/drugs/DB00999 (accessed on 9 August 2018).

11. Mahajan, A.A.; Thaker, A.K.; Mohanraj, K. LC, LC-MS/MS studies for the identification and characterization of degradation products of hydrochlorothiazide and establishment of mechanistic approach towards degradation. J. Braz. Chem. Soc. 2012, 23, 445-452. [CrossRef]

12. Brigante, M.; DellaGreca, M.; Previtera, L.; Rubino, M.; Temussi, F. Degradation of hydrochlorothiazide in water. Environ. Chem. Lett. 2005, 2, 195-198. [CrossRef]

13. Gupta, V.K.; Fakhri, A.; Azad, M.; Agarwal, S. Synthesis of CdSe quantum dots decorated $\mathrm{SnO}_{2}$ nanotubes as anode for photo-assisted electrochemical degradation of hydrochlorothiazide: Kinetic process. J. Colloid Interface Sci. 2017, 508, 575-582. [CrossRef] [PubMed]

14. Radjenović, J.; Petrović, M.; Barceló, D. Fate and distribution of pharmaceuticals in wastewater and sewage sludge of the conventional activated sludge (CAS) and advanced membrane bioreactor (MBR) treatment. Water Res. 2009, 43, 831-841. [CrossRef] [PubMed] 
15. Bourgin, M.; Beck, B.; Boehler, M.; Borowska, E.; Fleiner, J.; Salhi, E.; Teichler, R.; Von Gunten, U.; Siegrist, H.; McArdell, C.S. Evaluation of a full-scale wastewater treatment plant upgraded with ozonation and biological post-treatments: Abatement of micropollutants, formation of transformation products and oxidation by-products. Water Res. 2018, 129, 486-498. [CrossRef] [PubMed]

16. Sirés, I.; Brillas, E.; Oturan, M.A.; Rodrigo, M.A.; Panizza, M. Electrochemical advanced oxidation processes: Today and tomorrow. A review. Environ. Sci. Pollut. R. 2014, 21, 8336-8367. [CrossRef] [PubMed]

17. Martínez-Huitle, C.A.; Brillas, E. Decontamination of wastewaters containing synthetic organic dyes by electrochemical methods: A general review. Appl. Catal. B-Environ. 2009, 87, 105-145. [CrossRef]

18. Canizares, P.; Paz, R.; Sáez, C.; Rodrigo, M.A. Costs of the electrochemical oxidation of wastewaters: A comparison with ozonation and Fenton oxidation processes. J. Environ. Manag. 2009, 90, 410-420. [CrossRef] [PubMed]

19. Sirés, I.; Brillas, E. Remediation of water pollution caused by pharmaceutical residues based on electrochemical separation and degradation technologies: A review. Environ. Int. 2012, 40, $212-229$. [CrossRef] [PubMed]

20. Brillas, E.; Sirés, I.; Oturan, M.A. Electro-Fenton process and related electrochemical technologies based on Fenton's reaction chemistry. Chem. Rev. 2009, 109, 6570-6631. [CrossRef] [PubMed]

21. Bagastyo, A.Y.; Batstone, D.J.; Rabaey, K.; Radjenovic, J. Electrochemical oxidation of electrodialysed reverse osmosis concentrate on $\mathrm{Ti} / \mathrm{Pt}-\mathrm{IrO}_{2}, \mathrm{Ti} / \mathrm{SnO}_{2}-\mathrm{Sb}$ and boron-doped diamond electrodes. Water Res. 2013, 47, 242-250. [CrossRef] [PubMed]

22. Moreira, F.C.; Boaventura, R.A.; Brillas, E.; Vilar, V.J. Electrochemical advanced oxidation processes: A review on their application to synthetic and real wastewaters. Appl. Catal. B-Environ. 2017, 202, 217-261. [CrossRef]

23. Al-Qaim, F.F.; Mussa, Z.H.; Othman, M.R.; Abdullah, M.P. Removal of caffeine from aqueous solution by indirect electrochemical oxidation using a graphite-PVC composite electrode: A role of hypochlorite ion as an oxidising agent. J. Hazard. Mater. 2015, 300, 387-397. [CrossRef] [PubMed]

24. Mussa, Z.H.; Al-Qaim, F.F.; Othman, M.R.; Abdullah, M.P. Removal of simvastatin from aqueous solution by electrochemical process using graphite-PVC as anode: A case study of evaluation the toxicity, kinetics and chlorinated by-products. J. Environ. Chem. Eng. 2016, 4, 3338-3347. [CrossRef]

25. Mussa, Z.H.; Al-Qaim, F.F.; Othman, M.R.; Abdullah, M.P.; Latip, J.; Zakria, Z. Pseudo first order kinetics and proposed transformation products pathway for the degradation of diclofenac using graphite-PVC composite as anode. J. Taiwan Inst. Chem. Eng. 2017, 72, 37-44. [CrossRef]

26. Deborde, M.; Von Gunten, U.R.S. Reactions of chlorine with inorganic and organic compounds during water treatment-kinetics and mechanisms: A critical review. Water Res. 2008, 42, 13-51. [CrossRef] [PubMed]

27. Soufan, M.; Deborde, M.; Legube, B. Aqueous chlorination of diclofenac: Kinetic study and transformation products identification. Water Res. 2012, 46, 3377-3386. [CrossRef] [PubMed]

28. Soufan, M.; Deborde, M.; Delmont, A.; Legube, B. Aqueous chlorination of carbamazepine: Kinetic study and transformation product identification. Water Res. 2013, 47, 5076-5087. [CrossRef] [PubMed]

(C) 2018 by the authors. Licensee MDPI, Basel, Switzerland. This article is an open access article distributed under the terms and conditions of the Creative Commons Attribution (CC BY) license (http://creativecommons.org/licenses/by/4.0/). 